\title{
Learning Outcomes Assessment Formats in Georgia after USSR
}

\section{Shorena Gogiashvili*}

\section{ARTICLE INFO}

Article history:

Accepted: October 102020.

Approved: December 152020

\section{Keywords:}

Assessment

HEI stakeholders

Learning outcomes

Education

\section{A B S T R A C T}

The system of higher education in Georgia has been recently facing major challenges, especially in matching its outcomes to market and society demands. As the job market is becoming more globally competitive, these challenges are increasing.

To survive in the current business world, there is high competition between companies for highly qualified manpower. Higher education systems are, on the other hand, traditionally considered conservative and slow in response to market needs.

HEIs have many stakeholders: parents, students, faculty members, graduates, employees, regulatory organizations, and government. Their expectations are different and often are in conflict with one another in many respects. Multi-stakeholder involvement in the assessment of learning outcomes is essential to realize students' achievements. In these processes participation, collaboration and learning are emphasized. Participation leads to the perfect rating of the process and better evaluations of the outcomes.

The assessment of students/graduates by stakeholders is shaped by their participation in activities and their experiences in the processes. Understanding stakeholder importance in the processes in which they are involved and their evaluation of outcomes is imperative; it influences the current and future levels of engagement and improvement.

(C) 2020 Published by the Institute for Development Studies,

Sulkhan-Saba Orbeliani University.

\section{Introduction}

The introduction of the term 'learning outcomes' (LOs) is connected with the development of a student-centered approach to education. The debate on LOs vs. teaching goals has lasted for almost half a century. If the earlier widely spread term 'teaching goals' was teacher-centered and dealt with the goals that the instructor planned for teaching students, 'learning outcomes' is something that learners desire/need/ plan to know and be able to do after studying the course/program. "Using a combination of the learning outcomes approach and student workload in program design and delivery puts the student in the center of the teaching and

* Ph.D. Student, Sulkhan-Saba Orbeliani University, Tbilisi, Georgia. 


\section{JOURNAL OF DEVELOPMENT STUDIES}

learning process" (European Parliament, 2018, p.50).

Learning outcomes came to the center of educationalists' attention all over Europe in connection with European integration and especially the Bologna process. The Europe of the XXI century is not only politically, economically, scientifically, educationally, and culturally integrated, it stresses the need to take into consideration every person's peculiarities and needs. Thus, standards, which provide a high level and reputation of European education, co-exist with respect towards each country's traditions and each learner's abilities and demands. The development of common educational policy enhanced focusing on democratic values in education, which dealt with increased studentcenteredness: student autonomy, student (and other stakeholders') involvement in decision making, growth of students' roles in the educational process, application of inductive and interactive teaching methods (Todorovski et al. 2015).

"In the European Higher Education Area (EHEA), learning outcomes were first mentioned in the 2003 Berlin Communiqué - not as a stand-alone goal, but as one tool to achieve comparable degrees and underpin structural reforms in the context of the Bologna Process" (Peterbauer \& Zhang, 2020). Hoidn (2016) names learning outcomes as one of the four corner-stones of the Bologna process: LOs, student-centered teaching and learning methods, professional development of higher education academic personnel, and student support services. Gaebel and Zhang (2018) state that among the advantages of learning outcomes (instead of teaching goals) approach include easier recognition of credits, revision of course contents, teaching and assessment methods (to make them more student-centered), and collaboration among all stakeholders.

To consolidate the EHEA, meaningful implementation of learning outcomes is needed. The development, understanding, and practical use of learning outcomes is crucial to the success of ECTS, the Diploma Supplement, recognition, qualifications frameworks, and quality assurance (QA) - all of which are interdependent. Bologna Secretariat (according to the EHEA, 2012) stated: "We welcome the clear reference to ECTS, to the European Qualifications Framework and to learning outcomes in the European Commission's proposal for a revision of the EU Directive on the recognition of professional qualifications. We underline the importance of taking appropriate account of these elements in recognition decisions."

By providing a direct evaluation of student learning outcomes at the global stage and to enable institutions to benchmark the performance of their students against their peers as part of their improvement efforts, a new concept was introduced - the Assessment of Higher Education Learning Outcomes (AHELO), which aims to complement institution-based assessments. AHELO is the first international attempt at measuring higher education student learning outcomes across borders, languages, and cultures; it is by no means unique or isolated. Later some similar efforts followed. So, nowadays AHELO is part of a broader context of distinct initiatives converging in their focus on performance, competencies, and learning outcomes.

Given AHELO's global scope, it is essential that measures of learning outcomes are valid across diverse cultures and languages, as well as different kinds of higher education institutions (HEls). The development of Higher Education Learning Outcomes (HELOs) is a fairly new phenomenon in higher education that has recently attracted increasing interest. HELOs have attracted the interest of policy makers, quality assurance agencies, and university administrators amongst others, and engaged university teachers in formulating the expected or required 'outcome' of study programs. Importantly, the role of HELOs in 
the main activities of higher education teaching, assessment and learning - is not finite to impacts within higher education institutions, but should be seen in a broader policy and societal context, since HELOs are intended to provide stronger connections between these core activities, wider society and the labor market (according to the OECD, Organization for Economic Cooperation and Development, $2012 \mathrm{a}$; b).

Learning outcomes have repeatedly figured in Bologna-related events and documents grown to be an issue of considerable political significance. The Berlin Communiqué (2003), for instance, required that the degrees are based rather on learning outcomes than simply the number of credits. The Yerevan Communiqué $(2015$, p. 2), on the other hand, mentioned that student-centered learning should be supported by transparent descriptions of learning outcomes and workload, flexible learning paths, and appropriate teaching and assessment methods and that the application of LOs is crucial for graduates' employability.

The Bologna Process, thus, directing teachers' and students' attention to learning outcomes was defined as a pedagogical approach. Learning outcomes are experienced as influencing teaching plans and practice to various degrees.

Learning outcomes are concerned with the achievements (knowledge, skills, and employability) of the learner rather than the intentions of the teacher (expressed in the aims of a module or a course). However, ideally, they should be as close as possible to each other, as nowadays students are customers in higher education, and, as known well, 'customer is the king', so instructors have to teach what the students need to know at the end of the course/program. Teachers need to pose such goals in front of themselves (what to teach to students), which most probably students will need to know and/or be able to do.
Some other countries are not so much concentrated on learning outcomes, in the US, for instance, a greater emphasis has been put on the results of the Spellings Commission (Commission on the Future of Higher Education, 2006), stressing standardized tests for the measurement of outcomes in higher education, as well as federal guidelines to aid the accrediting bodies in developing national standards and comparative reviews of institutional performance (Busse et al., 2010).

Learning outcomes are key to meaningful education, and focusing on them is essential in order to diagnose the state of teaching/learning/knowledge and to improve the teaching processes and student learning. Although there is a long tradition of learning outcomes' assessment within institutions' courses and programs, the stress on learning outcomes has become more important in recent years, especially within the Bologna process. The interest in developing comparative measures of learning outcomes has increased in response to a range of higher education trends, challenges and paradigm shifts.

\section{Assessment in education}

Assessment is an inseparable component of the educational system. If in the past in Georgia during USSR regime mostly students (their knowledge and skills) were assessed, nowadays everything - educational policies, institutions, programs, curricula and syllabi, materials, lecturers and courses delivered by them, as well as students' knowledge, skills and attitudes - has to be assessed in order to provide high-quality education.

\section{Definition of assessment}

According to some sources assessment is the collection of relevant information that maybe relied on for making decisions. Evaluation, on the other hand, is the application of a standard and a decision-making system to 
assessment data to produce judgments about the amount and adequacy of the learning that has taken place. This definition can apply to any sphere of life - production, services, and education.

As for assessment in education, according to the online Glossary of Educational Reform (2014), "the term assessment refers to the wide variety of methods or tools that educators use to evaluate, measure, and document the academic readiness, learning progress, skill acquisition, or educational needs of students". Assessment in education is needed for decision making concerning students, educational institution and country accountability, establishing standards, planning the reforms and changes needs, student placement, diagnosing students' weaknesses and teachers' challenges in order to improve learning and teaching, and developing research, learning needs identification and educational research.

Some authors state that assessment refers to a variety of tasks by which teachers collect information regarding the performance and achievement of their students. The researchers highlight that assessment has two main purposes. One reason is for student learning and the other is for certification ('assessment of learning'), which involves the evaluation of student achievement (Carless, 2015). Formative and summative assessments fulfill these purposes (Carless, 2015; Saifi et al., 2011; Sambell et al., 2013). As Carless (2007) states, when an assessment is successful, these two functions need to overlap. Formative assessment occurs continuously throughout the course (Saifi et al., 2011; Sambell et al., 2013). It inspires students to engage in the subject matter, which helps them become familiar with the information they are attempting to learn (Jacoby et. al, 2014). Active participation of students and teachers occurs for effective formative assessment. According to researcher McCoy when students are actively engaged in the activities, it results in deeper thinking and longterm retention of learned concepts. Improvements in learners' performances are achieved through supportive feedback from various assessment tasks (Sambell et al., 2013). Because of its value to learning, formative an assessment is considered assessment for learning (Hernández, 2012).

Student knowledge and skill assessment play an essential role in the quality of the educational process. It helps administration, teachers, and students to understand how much the learning outcomes have been achieved and how much chance there is that students succeed in their further learning and career. Assessment defines the quality and relevance of assessment methods (essays, objective testing, performance assessment, portfolios, etc.). It also helps policy makers, stakeholders, and educationists to implement curriculum properly. Over the past two decades, more emphasis compared to the past has been made on assessing learners' performance (Gebremedhin \& Asgele, 2015).

There is a debate on frequent changes and development in the assessment methods over the world. Traditionally, students were encouraged to demonstrate current knowledge and to play a passive role in the assessment process, rather than developing critical thinking abilities and being active in their own learning, as close-ended tests, so widely applied, require from students only reproductive knowledge instead of productive ones. Contemporary education is constantly looking for innovations that bring about improvement in teaching with the express purpose of improving student learning, it does its best to involve students in assessment and to make them responsible for their learning (Jogan, 2019).

Higher education institutions are continually striving to make education applicable to the working environment that their former students will encounter upon graduation. 
One of the tools for enhancing an institution's quality and sufficiently informing students about their outcomes and learning opportunities is quality assessment. Quality assessment is a long process that establishes measurable student learning outcomes, then analyses and interprets them. This enables students to receive an assessment on their learning and helps them to improve their performance (Čechová et al., 2019).

While teaching goals are not necessarily measurable, learning outcomes should be capable of being assessed (Adam, 2004, p. 4). Clearly, it is necessary to have some form of assessment tools in order to determine the degree to which the set learning outcomes have been achieved. Assessment techniques may be direct and indirect. Written examinations, project work, portfolios, grading system with rubrics, theses, reflective journals, performance assessment, etc. are direct measurements and surveys of employers, comparison with peer institutions, surveys of past graduates, retention rates, analysis of curriculum, etc. are indirect ones.

The minimum acceptable standard that learning outcomes specify, is to enable a student to pass a module. Student performance above this basic threshold level is differentiated by applying grading criteria. Grading criteria are statements that show what a student must demonstrate to achieve a higher grade. Rubrics - or 'multi-purpose scoring guides' (Wolf \& Stevens, 2007, p. 3) - help to differentiate the levels of performance of a student. It is hoped that students will aim for the highest levels of performance; however, the minimum (passing) levels are also needed, especially for struggling students who make a lot of effort, but still are not very successful. For formative assessment, many levels of performance help the student to improve gradually, while a few levels for summative assessment simplify teachers' job (Wolf \& Stevens, 2007, p. 7).

\section{Importance/role of learning outcomes assessment in higher education}

It is very important to assess whether higher education students have attained the desired outcomes. An assessment provides essential assurance to a wide variety of stakeholders that people have gained various knowledge and skills and that they are ready for employment or further study. More broadly, the assessment of LOs reflects the character of an institution and its educational programs. Much assessment is expensive, making it an influential focus for analysis. Assessment shapes education and how people study in powerful direct and indirect ways, influencing teaching and curriculum. Assessment is highly relevant to individuals, often playing a major role in defining life chances and directions (Zlatkin-Troitschanskaia et al., 2018).

It is very important that there is alignment between the learning outcomes and student assessment, as the goal of student knowledge and skills assessment should exactly deal with the degree of achievement of learning outcomes (Ulker, 2018). This is why the contemporary syllabus has to reveal which assessment method has to assess which LO and how exactly it will be done.

Table 1 shows the desirable format of presenting learning outcomes-to-student assessment:

Table 1

The format of presenting learning outcomes-tostudent assessment

\begin{tabular}{|l|l|l|l|l|}
\hline & $\begin{array}{l}\text { Assess- } \\
\text { ment for- } \\
\text { mat 1 } \\
\text { (e.g., } \\
\text { multiple- } \\
\text { choice } \\
\text { test) }\end{array}$ & $\begin{array}{l}\text { Assess- } \\
\text { ment for- } \\
\text { mat 2 } \\
\text { (e.g., case } \\
\text { studies - } \\
\text { offering } \\
\text { solutions) }\end{array}$ & $\begin{array}{l}\text { Assess- } \\
\text { ment for- } \\
\text { mat 3.... }\end{array}$ & $\begin{array}{l}\text { Assess- } \\
\text { ment for- } \\
\text { mat n }\end{array}$ \\
\hline $\begin{array}{l}\text { Learning out- } \\
\text { come 1 (e.g., } \\
\text { knowledge of } \\
\text { the factual ma- } \\
\text { terial in the } \\
\text { course) }\end{array}$ & $\mathrm{X}$ & & \\
\hline
\end{tabular}




\section{JOURNAL OF DEVELOPMENT STUDIES}

\begin{tabular}{|c|c|c|c|c|}
\hline $\begin{array}{l}\text { Learning out- } \\
\text { come } 2 \text { (e.g., } \\
\text { problem-solv- } \\
\text { ing skills) }\end{array}$ & & $x$ & $X$ & \\
\hline $\begin{array}{l}\text { Learning out- } \\
\text { come } 3 . . .\end{array}$ & & & $x$ & $x$ \\
\hline $\begin{array}{l}\text { Learning out- } \\
\text { come } n\end{array}$ & $x$ & & $x$ & \\
\hline
\end{tabular}

It is visible from the table that each outcome does not need to fit each assessment format (this would be impossible), but on the whole all course outcomes are met by a certain assessment format(s).

According to some scholars external stakeholders - governments, accrediting agencies, potential students and their parents - are holding institutions of higher education increasingly accountable for the quality of education they are providing their students. Assessment grades are one of the signs by which they can understand how good the teaching and assessment quality is: if too many students fail, it means that either teaching is not relevant and/or there is a discrepancy between assessment methods and teaching methods. On the other hand, if almost all students get high grades, it reveals that either the taught materials are too simple and/or so are the assessment methods. In both cases, there are some problems with the quality of teaching and learning.

According to Jonson, Guetterman, and Thompson (2014), the assessment of student learning outcomes can influence program improvement. Many authors support the view on the positive role of LOs assessment in the enhancement of program quality.

Who knows better than program graduates and their employers whether they gained learning outcomes that were relevant to the job needs? 'Evaluative thinking' is beneficial, as it challenges stakeholders in the program to ask critical questions about what the intended effects of the program are, how they could be measured, and what causal connection they have to elements of the program. Most evaluation theories: behavioral, stressing testing and measurement, as well as humanistic and cognitive, emphasizing personal and intellectual development (Szőköl, 2016), underline the importance of stakeholder involvement in building the evaluation capacity. Frye and Hemmer (2012) discuss several theories of educational evaluation: reductionist theory, which tries to find the impact of changes on the quality of education via experimenting on separate constituents of the educational program, Kirkpatrick's four-level model of learner outcomes, which studies the relationships between program components and learning outcomes, the Logic Model, which specifies the intended relationships between evaluation components, and Stufflebeam's Context, Input, Process and Product (CIPP) model, consistent with system theory and complexity theory: it is flexible enough to incorporate the studies that support ongoing program improvement as well as summative studies of a completed program's outcomes. While reductionist theory views the importance of stakeholders' participation in developing learning outcomes one by one, in isolation, the other theories view them in unity.

Clinton (2013) emphasized the significance of stakeholder engagement in LOs assessment for defining the quality of the program. Brandon \& Fukunaga (2014) provided more details on the empirical support for stakeholder engagement, noting some problems (e.g., the importance of adequate resources for building the evaluation capacity of stakeholders) along with clear indications of the pattern of positive effects on evaluation use and influence.

Various researches have revealed that adopting the learning outcomes-based approach is beneficial at the program (Clarke \& Reichgelt, 2003), individual courses as well as at society levels (Gowan et al., 2006). However, there are criticisms in connection with the issue as well. In particular, Havnes \& Prøitz (2016) mention that by telling students the learning outcomes, universities sort of 


\section{JOURNAL OF DEVELOPMENT STUDIES}

providing a message that the outcomes are not only necessary but also sufficient, thus, limiting students' strive for better achievement.

\section{How to measure the achievement of learning outcomes}

Based on the discussion above, it is possible to sum up that to measure the achievement of learning outcomes, it is essential to define:

$\checkmark$ whether the curricula/programs are relevant to educational policies in the country; $\checkmark$ whether the educational materials enable students to develop the required knowledge, skills, and values/attitudes;

$\checkmark$ whether the teaching and assessment methods and the outcomes are congruent to each other;

$\checkmark$ whether the offered objective tests enable to measure the expected knowledge and understanding;

$\checkmark$ what percentage of students fail - pass

- succeed in tests;

$\checkmark$ whether the open-ended tasks (essays, presentations, projects, research) permit to measure critical thinking, application of cognitive/metacognitive strategies.

The relevance of programs to educational policies is usually measured in the process of internal assessment (through questionnaires) and external assessment (authorization by national and international bodies) (Anderson et al., 2005). According to Harden, Crosby, and Davis (1999), "in outcome-based education, product defines the process. Outcomebased education can be summed up as 'results-orientated thinking' and is the opposite of 'input-based education' where the emphasis is on the educational process and where we are happy to accept whatever is the result (p.8)". To help people involved in program development satisfy the assessment requirements, special program/curriculum guides are being developed by governmental agencies".

The efficient assessment uses quantitative, qualitative, direct, and/or indirect measures to define whether the learning outcomes have been achieved. The quality of educational materials, relevance of teaching, and assessment methods to the expected LOs can be accessed via teacher and student questionnaires and/or interviews with them. If the questionnaires apply close-ended (Likert scale or multiple choice) items only, the measures will be quantitative, if the items are open-ended, the measure will be qualitative, if both types of items are applied, then the measure will be mixed. Interviews represent qualitative measures. The direct measures are testing students (open-ended tasks in tests should be accompanied by rubrics to achieve objectivity), while questionnaires and interviews are indirect measures of |LOs fulfillment. The combination of all tools will provide the most relevant picture.

It is necessary to clarify whether teachers find the materials teachable (arranged from the easy to the difficult, with sufficient effective activities) and whether students find them learnable (easy enough) (Ashiem et al., 2007). Teachers are responsible for both selecting effective teaching methods and helping students apply effective learning methods. Assessment methods have to be objective and corresponding to the expected LOs.

How learnable the materials are and whether the teaching/learning/assessment methods are relevant can be also understood from the testing results:

$\checkmark$ if too many students (say, $70 \%$ or more) fail the tests, it means that either the materials were too difficult and teacher expectations too high or that the test was too difficult;

$\checkmark$ on the other hand, if - too many students (say, $70 \%$ or more) fulfill the test correctly, it means that either the materials 


\section{JOURNAL OF DEVELOPMENT STUDIES}

were too easy and teacher expectations too low or that the test was too simple.

Understanding the quality of the openended tasks is the most difficult, thus, indepth interviews will be more effective for that purpose than a multiple-choice or Likertscale questionnaire.

According to Keshavarz direct measures of LOs achievement are provided by testing, portfolios, projects, and performance tasks. Both generic and discipline-specific knowledge and especially skills are more efficiently measured by performance tasks (portfolios, role play, business games and internships) rather than constructed-response and multiple-choice tasks (OECD 12a). A reliable assessment consistently achieves the same results with the same or similar group of students. Reliability may be decreased by ambiguous questions, vague marking instructions, and insufficiently qualified markers. A valid assessment measures what it is intended to measure. A test result is viewed as valid when it properly assesses what the syllabus names as LOs.

Summative and formative assessments are often described as 'assessment of learning' - and 'assessment for learning', - respectively (Earl, 2003). For formative assessment of the educational process, on the one hand, teacher observations and reflections (selfand peer-reflections) will be used. University quality assurance may develop and apply questionnaires to find out teachers' assessment of the process. For summative assessment tests involving both close-ended and open-ended questions (including essays, analysis, etc.) will be applied.

\section{Conclusion}

So, to conclude While writing/formulating LOs, it is necessary to concentrate on student knowledge and especially skills (particular actions that students are expected to fulfill quickly, easily, and automatically). Making the wording "SMART" - specific, measurable, attainable, relevant, and time-bound - is possible through cooperation with stakeholders step by step. Clear (comprehensible) LOs are helpful for both students and their future employers.

\section{References}

Adam, S. (2004). Using learning outcomes: A consideration of the nature, role, application and implications for European education of employing "learning outcomes" at the local, national and international levels. United Kingdom Bologna Seminar. Edinburgh, UK: HeriotWatt University. http://www.ehea.info/media.ehea.info/file/Learning Outcomes Edinburgh 2004/76/8/040620LEARNING OUTCO MES-Adams 577768.pdf

Anderson, H. M., Anaya, G. Bird, E. Moore, D. L. (2005). A review of educational assessment. American Journal of Pharmaceutical Education, 69 (2), article 12. https://www.ajpe.org/doi/full/10.5688/aj690 $\underline{239}$

Ashiem, C., Gowan, A., Reichgelt, H. (2007). Establishing an assessment process for a computing program. Information Systems Education Journal, 5(1), 23-25.

Brandon, P. R., Fukunaga, L. (2014). A review of the findings of empirical studies of stakeholder involvement in program evaluations. American Journal of Evaluation, 35, 26-44.

Busse, J. Goymal, A., Wahal, S. (2010). Performance and Persistence in Institutional Investment Management. The Journal of Finance, 65, 2, 765-790.

Carless, D. (2015). Excellence in University Assessment: Learning from Award-Winning Practice. London: Routledge.

Clarke, F., Reichgelt, H. (2003). The importance of explicitly stating educational objectives in Computer Science curricula. ACM SIGCSE Bulletin, 35 (4), 47-50. (1), 1225.

Čechová I., Neubauer, J., Sedlačík, M. (2019, March). Tracking the university student success: Statistical quality assessment. 


\section{JOURNAL OF DEVELOPMENT STUDIES}

Journal on Efficiency and Responsibility in Education and Science, 12.

Clinton, J. (2013). The true impact of evaluation: Motivation for ECB. American Journal of Evaluation, 35(1):120-127.

European Parliament (2018). Decision (EU) 2018/646 of the European Parliament and of the Council of 18 April 2018 on a common framework for the provision of better services for skills and qualifications (Europass) and repealing Decision No 2241/2004/EC. Retrieved January 25, 2010, from https://eur-lex.europa.eu/legal-content/EN/TXT/PDF/?uri=CELEX:32018D0646\&ri $\underline{d=9}$

Gebremedhin, M. A., Asgele, B. (2015). Assessing quality of education: In perspective with continuous assessment and learners' performance in Adwa College, Ethiopia. Developing Country Studies, 5, 9, 1-9.

Glossary of Educational Reform, 2014, https://www.edglossary.org/

Gowan, A., MacDonald, B., Reichgelt, H. (2006). A configurable assessment information system. Proceedings of 7th Conference on Information Technology Education, SIGITE, 77-92.

Harden, R. M., Crosby, J. R., Davis, M. H., Friedman, M. (1999). AMEE Guide No. 14: Outcome-based education: Part 5-From competency to meta-competency: a model for the specification of learning outcomes. Med Teach. 21(6):546-52. doi: 10.1080/01421599978951. PMID: 21281173.

Havnes, A., Prøitz, T.S. (2016). Why use learning outcomes in higher education? Exploring the grounds for academic resistance and reclaiming the value of unexpected learning. Educational Assessment, Evaluation and Accountability, 28 (3), 205-23.

Hernández, R. (2012). Does continuous assessment in higher education support student learning? Higher Education, 64(4), 489-502.

Hoidn, S. (2016). The pedagogical concept of student-centered learning in the context of European higher education reforms. European Scientific Journal, 12 (28), 439-458.

Jogan, S. N. (2019). Assessment for learning or of learning: A perception of trainees. International Journal of Research in Social Sciences, 9, (1), 548-554.
Jonson, J., Guetterman, T., Thompson, R. (2014). An integrated model of influence: Use of assessment data in higher education. Research \& Practice in Assessment, 9, 18-30.

Peterbauer, H., Zhang, T. (2020). Learning outcomes: why we need a common language be tween the worlds of work and education. European Universities' Association. Retrieved July 2, 2020, from https://eua.eu/resources/expert-voices/162:learning-outcomes-why-we-need-a-common-languagebetween-the-worlds-of-work-and-education.html

Saifi, S., Mahmood, T., Gujjar, A. A., Ali Sha, S. S. (2011). Assessing the quality of assessment techniques at higher education level. International Journal of Business \& Social Science, 2(12), 273-280.

Sambell, K., McDowell, L., Montgomery, C. (2013). Assessment for Learning in Higher Education. ISBN 9780415586580. Published July 30, 2012 by Routledge. 184 Pages.

Szőköl, I. (2016). The Theory of Educational Evaluation. Eger: EszterházyKároly University of Applied Sciences.

Todorovski, B., Nordal, E., Isoski, T. (2015). Overview on Student-Centered Learning in Higher Education in Europe. Brussels: Peer Assessment of Student-Centered Learning (PASCL).

Ulker, V. (2018). Alignment of Learning Outcomes, Course Content, and Assessment in English as a Foreign Language Program (University Language Preparatory School). Ph.D. dissertation. Tbilisi: International Black Sea University.

Wolf, K., Stevens, E. (2007). The role of rubrics in advancing and assessing student learning. Journal of Effective Teaching, 7(1), 3-14.

Zlatkin-Troitschanskaia, O., Toepper, M., Pant, H. A., Lautenbach, C., \& Kuhn, C. (Eds.) (2018). Assessment of Learning Outcomes in Higher Education.Berlin: Springer. 